\title{
PENGARUH PENDIDIKAN KESEHATAN PEMERIKSAAN PAYUDARA SENDIRI (SADARI) TERHADAP PERILAKUDETEKSI DINI KANKER PAYUDARA PADA WANITA USIA SUBUR (WUS) DI WILAYAH KERJA UPTD PUSKESMAS KAMPUNG BANGKA KECAMATAN PONTIANAK TENGGARA
}

\section{(The Effects Of Health Education Concerning Breast Self-Examination On Early Detection Behaviour Of Breast Cancer On Women Of Reproductive Age In The Regional Technical Implementation Unit at the Community Health Center in Kampung Bangka, Southeast Pontianak District)}

\author{
Melsi Yunanda Sella ${ }^{1}$, Hafrizal Riza $^{2}$, Suhaimi Fauzan $^{3}$ \\ ${ }^{1}$ Program Studi Ilmu Keperawatan, Fakultas Kedokteran, Universitas Tanjungpura Melsiyunandsella@gmail.com \\ ${ }^{2}$ Fakultas Kedokteran, Universitas Tanjungpura Hafrizal.riza@ gmail.com \\ ${ }^{3}$ Program Studi Ilmu Keperawatan, Fakultas Kedokteran, Universitas Tanjungpura Suhaimi.fauzan@ners.untan.ac.id
}

\begin{abstract}
ABSTRAK
Latar Belakang :Kanker payudara merupakan kanker yang paling sering terjadi pada wanita. Sebanyak 60-70\% wanita dengan kanker payudara berobat pada stadium lanjut sehingga sulit untuk disembuhkan,padahal kanker payudara dapat dideteksi pada stadium awal dengan pemeriksaan payudara sendiri (SADARI). SADARI merupakan cara yang paling efektif untuk pencegahan dini kanker payudara. Pengetahuan dan persepsi mengenai kanker payudara akan mempengaruhi perilaku SADARI seseorang.

Tujuan :Mengetahui pengaruh pendidikan kesehatan SADARI terhadap perilaku deteksi dini kanker payudara pada wanita usia subur (WUS).

Metode :Penelitian bersifat kuantitatif, menggunakan desain quasi experiment (pre test and post test nonequivalent control group. Sampel pada penelitian ini sebanyak 106 WUS terbagi dalam kelompok intervensi dan kelompok kontrol. Analisa data menggunakan uji Wilcoxon dan Mann-Whitney.

Hasil : Analisis uji Wilcoxon pada perilaku SADARI pada kelompok intervensi sebelum dan sesudah diberi perlakuan menunjukkan nilai $p$ value $0,000<0,05$ dan hasil uji Mann-Whitney pada post test intervensi dan post test kontrol diperoleh nilai p-value $0,000<0,05$ yang berarti terdapat perubahan yang bermakna terhadap kelompok intervensi.

Kesimpulan :Terdapat pengaruh pendidikan kesehatan SADARI terhadap perilaku deteksi dini kanker payudara pada WUS di wilayah kerja UPTD Puskesmas Kampung Bangka Kescamatan Pontianak Tenggara.
\end{abstract}

Kata Kunci :Pendidikan kesehatan, Perilaku SADARI, WUS 


\begin{abstract}
Background: Breast cancer is the most common malignancy in women. As many as 60-70\% of women who suffer from breast cancer seek treatment at an advanced stage. This makes their disease difficult to cure, even though breast cancer can be detected at an early stage by breast self-examination (BSE). BSE is the most effective way to prevent early breast cancer. Knowlodge and perceptions of breast cancer will affect one's BSE behavior.

Objective: Acknowledging the effect of BSE health education on early breast cancer detection behavior in women of reproductive age.

Method: This research is Quantitative by using a quasi experimental design, which is per-test and post-test non-equivalent control group. The sample in this study were 106 women of reproductive age who were divided into intervention and control groups. Data analysis in this study employed the Wilcoxon and Mann-Whitney tests.

Result: The analysis of the Wilcoxon test on BSE behavior in the intervention group before and after treatment explicated p-value of 0,000 <0,05. On the other hand, the result of the Mann-Whitney test on the post-test of intervention and the post-test control obtained a pvalue of 0,000 0,05 which was a significant change in the intervention group.

Conclusion: There is an effect of BSE health education on early breast cancer detection behavior in women of reproductive age in the Regional Technical Implementation Unit at the Community Health Center in Kampung Bangka, Southeast Pontianak District.
\end{abstract}

Keywords: Health education, Breast self-examination (BSE) behavior, Women of reproductive age

PENDAHULUAN

Di dunia penyakit kanker merupakan salah satu penyebab kematian yang utama (Kemenkes RI, 2013).Kanker payudara merupakan kanker yang paling sering terjadi pada perempuan sebesar $22 \%$ dari semua kasus baru kanker pada perempuan dan di dunia menjadi penyebab utama kematian akibat kanker sebesar $14 \%$ dari semua kejadian kematian yang diakibatkan kanker pada perempuan. Terdapat berbagai faktor yang diperkirakan meningkatkan risiko kanker payudara, antara lain faktor usia, riwayat keluarga, hormonal, gaya hidup seperti kurangnya aktivitas fisik/olahraga serta pola makan, faktor lingkungan, dan adanya riwayat tumor jinak.
Berdasarkan data GLOBOCAN, International Agency for Research on Cancer (IARC) pada tahun 2012 terdapat insiden kanker payudara sebesar 40 per 100.000 perempuan di dunia (Kemenkes RI, 2016). Sedangkan, menurut World Health Organization (WHO) jumlah kematian akibat kanker meningkat dari 8,2 juta pada tahun 2012 menjadi 8,8 juta kematian pada tahun 2015. Kanker payudara menempati urutan kelima dalam penyebab paling umum kematian akibat kanker dengan angka kejadian sebesar 571.000 kematian (WHO, 2017). Di Indonesia, pada tahun 2013 kanker payudara merupakan kanker dengan prevalensi tertinggi. Dari data RS Kanker Dharmais selama tahun 2010-2013 kanker 
payudara memiliki jumlah kasus baru serta jumlah kematian yang terus meningkat (Kemenkes RI, 2015).

Menurut data Sistem Informasi Rumah Sakit (SIRS) Provinsi Kalimantan Barat angka kejadian kanker payudara berdasarkan data rawat jalan dan rawat inap adalah 429 kasus dengan 32 angka kematian pada tahun 2016, angka ini meningkat dari dua tahun sebelum nya dimana pada tahun 2014 tercatat ada 162 kasus dan 5 angka kematian akibat kanker payudara. Cakupan deteksi dini kanker payudara menurut profil kesehatan Kabupaten/Kota Provinsi Kalimantan Barat tahun 2017 yang telah dilakukan oleh 14.098 orang memiliki penemuan sebaran terbanyak di Kota Pontianak berjumlah 99 orang dan ikuti kabupaten lainnya. Kota Pontianak menempati urutan pertama angka kejadian kasus dari dua belas kabupaten dan dua kota(Dinkes Kota Pontianak, 2018).

Terdapat pengobatan kanker payudara seperti pembedahan, radioterapi, kemoterapi, terapi hormon, dan terapi biologis (target terapi). Namun apabila kanker terlambat terdiagnosa maka akan menyebabkan pengobatannya menjadi terhambat dan kurang efektif (Integra, 2017). Berdasarkan data pasien di RS Kanker Dharmais, selama tahun 2010-2015 sebanyak 60-70\% penderita kanker payudara yang datang untuk pengobatan sudah dalam stadium III-IV (stadium lanjut) (Kemenkes
RI, 2016).Penting dilakukannya deteksi dini kanker payudara untuk mendeteksi kanker payudara lebih awal agar penyebaran nya dapat dicegah dan kematian akibat kanker payudara dapat dikurangi (Jarvis, 2009).

Deteksi dini dapat menekan angka kematian sebesar 25-30\%. Deteksi dini juga dapat meningkatkan kesembuhan penderita kanker payudara dengan penemuan dini, diagnosis dini, dan terapi dini(Rasjidi, 2010). Deteksi dini kanker payudara diantaranya adalah pemeriksaan payudara sendiri (SADARI), Pemeriksaan payudara klinis (SADANIS), dan Mamografi.Menurut American Cancer Society (ACS) pemeriksaan payudara klinis maupun pemeriksaan payudara sendiri kurang di direkomendasikan dalam deteksi dini karena kurangnya bukti pendukung dan masih adanya kemungkinan hasil positif palsu(Yuliana, 2018).Namun, temuan adanya tonjolan, nyeri, serta penebalan kulit dan penemuan lainnya yang ada pada payudara dapat menunjukkan adanya kelainan (tumor) pada payudara (Kemenkes RI, 2015).Dengan melakukan pemeriksaan payudara sendiri (SADARI) sebagian besar tumor ditemukan oleh wanita sendiri dan dapat membuat wanita lebih waspada terhadap keadaan payudara mereka, sehingga dapat mencegah terjadinya kanker payudara.Program ini merupakan program yang cocok untuk negara berkembang karena program yang ditawarkan sederhana, murah, non-invasif, 
dan tidak

berbahaya(Priyoto,

2015).Pemeriksaan payudara sendiri dapat menemukan kanker payudara hingga 75-85\% jika dilakukan secara rutin(Hanifah, 2015).Sedangkan, untuk pemeriksaan mammografi membutuhkan biaya dan fasilitas yang belum tersedia di setiap fasilitas kesehatan(Yuliana, 2018).

Meskipun SADARI tidak mahal, tidak nyeri, tidak berbahaya dan nyaman, namun hanya sekitar dua pertiga wanita mempraktikkannya sekurang-kurangnya sekali setahun dan hanya sepertiga mempraktekkannya tiap-tiap bulan seperti dianjurkan.Wanita yang melakukan teknik itu, hanya sekitar setengahnya yang melakukan dengan benar. Hal ini disebabkan karena minimnya informasi dan kurangnya pengetahuan tentang SADARI(Wardhani, Saraswati, \& Adi, 2017).

Dalam penelitian Wulandari dan Ayu (2017) mengungkapkan bahwa sebagian besar orang menunjukkan masih kurangnya pengetahuan tentang SADARI. Kurangnya pengetahuan masyarakat mengenai SADARI disebabkan kurang terpaparnya informasi mengenai SADARI, baik dari media cetak, media elektronik, maupun kerabat dekat. Kurangnya pengetahuan mengenai SADARI dapat mempengaruhi perilaku dalam mengaplikasikan SADARI.Kurangnya pengetahuan mengenai prosedur SADARI membuat seseorang tidak mengaplikasikan
SADARI sebagai kebiasaan rutin dalam upaya deteksi dini kanker payudara.

Menurut teori Health Belief Model (HBM) perilaku sesorang dapat dipengaruhi oleh persepsi dan kepercayaan seseorang itu sendiri tanpa memandang apakah hal tersebut sesuai atau tidak dengan realitas yang ada. Teori ini didasari oleh faktor kesiapan individu dalam merubah perilaku untuk menghindari suatu penyakit atau resiko yang ada, adanya dorongan dari lingkungan yang dapat merubah perilaku, dan perilaku itu sendiri(Notoatmodjo, 2012).

Dari hasil wawancara yang dilakukan pada petugas kesehatan dan masyarakat di Puskesmas Kampung Bangka didapatkan bahwa kesadaran masyarakat khususnya wanita usia subur pada deteksi dini kanker payudara masih kurang hal ini dipengaruhi karena kurangnya pengetahuan terhadap kanker payudara.

Untuk mengatasi kurangnya kesadaran mengenai pemeriksaan payudara sendiri (SADARI) salah satunya adalah dengan meningkatkan persepsi tentang kanker payudara dan SADARI dengan pemberian pendidikan kesehatan kepada masyarakat khusus nya para wanita usia subur mengenai pentingnya SADARI dalam deteksi dini kanker payudara sehingga diharapkan dapat meningkatkan perilaku SADARI. Oleh karena hal itu peneliti merasa tertarik untuk melakukan penelitian mengenai Pengaruh Pendidikan Pemeriksaan 
Payudara Sendiri (SADARI) Terhadap Perilaku Deteksi Dini Kanker Payudara Pada Wanita Usia Subur.

\section{BAHAN DAN METODE}

Penelitian ini merupakan penelitian kuantitatif dengan desain penelitian quasy eksperiment yang menggunakan pendekatan pretest and posttest nonequivalent control group(Dharma, 2015). Penelitian ini dilakukan di Puskesmas Kampung Bangka Kecamatan Pontianak Tenggara mulai tanggal 6 juni sampai 11 juli 2018.Sampel penelitian sebanyak 106 respondenyang dibagi dalam dua kelompok yaitu 53 orang kelompok intervensi dan 53 orang kelompok kontrol.Pengambilan sampel menggunakan purposive sampling sesuai kreteria inklusi dan eksklusi.

Instumen penelitian adalah suatu alat yang digunakan untuk mengobservasi, mengukur atau menilai suatu fenomena.Instrumen yang digunakan oleh peneliti sebagai alat pengumpulan data adalah kuesioner.Kuesioner yang digunakan pada penelitian ini terdiri dari dua kuesioner.Untuk kuesioner pertama telah digunakan pada penelitian Kim dkk (2014) tentang pengetahuan dan persepsi kesehatan mengenai kanker payudara dan skrining kanker payudara, dengan beberapa pertanyaan dirubah dan ditambahkan untuk keperluan pelajaran ini. Sedangkan untuk kuesioner kedua dibuat sendiri oleh peneliti berdasarkan variabel yang akan diteliti.
Analisa data yang menggunakan analisa univariat dan bivariate. Analisa univariat digunakan terhadap data usia, tingkat pendidikan, dan pekerjaan. Sedangkan, untuk analisa bivariat menggunakan uji Mann-Whitney untuk mengetahui pengaruh pendidikan kesehatan pemeriksaan payudara sendiri (SADARI)terhadap perilaku deteksi dini kanker payudara.

\section{HASIL DAN PEMBAHASAN}

Hasil penelitian yang telah dilakukan pada tanggal sampai 6 juni sampai 11 juli 2018 dengan melibatkan 106 responden yaitu sebagai berikut:

1. Analisa univariat

Table 4.1 menunjukkan bahwa mayoritas penderita responden dalam penelitian ini berada pada umur remaja akhir (12-25 tahun) sebanyak 47,2\% (24 orang) pada kelompok intervensi dan $41,5 \%$ (22 orang) pada kelompok kontrol,untuk pendidkan sebagian besar berpendidikan SMA/SMK/Sederajat 50,9\% (27 orang) pada kelompok intervensi dan 49,1\% (26 orang) untuk kelompok kontrol, sedangkan untuk pekerjaan rata rata sebagai ibu rumah tangga 75,7\% (40 orang)untuk kelompok intervensi dan 79,2\% (42 orang untuk kelompok kontrol. 
Tabel 4.1

Distribusi karakteristik responden

\begin{tabular}{|c|c|c|c|c|}
\hline \multirow{3}{*}{$\begin{array}{c}\text { Karakteristik } \\
\text { Responden }\end{array}$} & \multicolumn{4}{|c|}{ Kelompok } \\
\hline & \multicolumn{2}{|c|}{ Intervensi } & \multicolumn{2}{|c|}{ Kontrol } \\
\hline & $\mathbf{N}$ & $(\%)$ & $\mathbf{n}$ & $(\%)$ \\
\hline $\begin{array}{c}\text { Usia } \\
(15-49 \text { th })\end{array}$ & & & & \\
\hline $\begin{array}{l}\text { Remaja akhir } \\
(17-25 \text { th) }\end{array}$ & 4 & $7,5 \%$ & 6 & $\begin{array}{c}11,3 \\
\%\end{array}$ \\
\hline $\begin{array}{c}\text { Dewasa awal } \\
(26-35 \text { th) }\end{array}$ & 25 & $47,2 \%$ & 22 & 41,5 \\
\hline $\begin{array}{l}\text { Dewasa akhir } \\
\text { (36-45 th) }\end{array}$ & 17 & $32,1 \%$ & 19 & $\%$ \\
\hline \multirow[t]{2}{*}{$\begin{array}{l}\text { Lansia awal } \\
\text { (46-49 th) }\end{array}$} & 7 & $13,2 \%$ & 6 & $\begin{array}{c}35,8 \\
\%\end{array}$ \\
\hline & & & & $\begin{array}{c}11,3 \\
\%\end{array}$ \\
\hline \multicolumn{5}{|l|}{ Pendidikan Terakhir } \\
\hline SD & 1 & $1,9 \%$ & 3 & $5,7 \%$ \\
\hline SMP & 13 & $24,5 \%$ & 16 & 30,2 \\
\hline SMA/SMK/Sederajat & 27 & $50,9 \%$ & 26 & $\%$ \\
\hline Perguruan Tinggi & 12 & $22,6 \%$ & 8 & $\begin{array}{c}49,1 \\
\% \\
15,1 \\
\%\end{array}$ \\
\hline \multicolumn{5}{|l|}{ Pekerjaan } \\
\hline IRT & 40 & $75,7 \%$ & 42 & 79,2 \\
\hline Swasta & 4 & $7,5 \%$ & 6 & $\%$ \\
\hline PNS & 9 & $17,0 \%$ & 5 & $\begin{array}{c}11,3 \\
\%\end{array}$ \\
\hline
\end{tabular}

Sumber: data primer, 2018

2. Analisa bivariat

Analisa bivariat digunakan untuk mengetahui pengaruh pendidikan kesehatan pemeriksaan payudara sendiri (SADARI)terhadap perilaku deteksi dini kanker payudara.Uji yang digunakan adalah uji MannWhitney. Adapun hasilnya dapat dilihat pada tabel 4.3 dibawah ini.

Tabel 4.3

Hasil uji pengaruh pendidikan kesehatan SADARI terhadap perilaku SADARI pada kelompok intervensi dan kontrol

\begin{tabular}{ccccc}
\hline & $\mathrm{N}$ & Median & $\begin{array}{c}\text { Min- } \\
\text { Max }\end{array}$ & $P$ \\
\hline $\begin{array}{c}\text { Post test } \\
\text { Intervensi }\end{array}$ & 53 & 1,00 & $0-2$ & 0,000
\end{tabular}

Post Test

Kontrol

Berdasarkan tabel 4.3 dapat disimpulkan bahwa hasil uji statistik dengan menggunakan uji $\mathrm{T}$ berpasangan didapatkan nilai $p=0,000$, artinya ada perbedaan antara tekanan darah sebelum dan sesudah intervensi terapi pijat refleksi kaki. Dengan demikian dapat disimpulkan bahwa ada pengaruh terapi pijat refleksi kaki terhadap perubahan tekanan darah sebelum dan sesudah dilakukan intervensi pada penderita hipertensi di wilayah kerja Puskesmas Kampung Dalam Kecamatan Pontianak Timur.

\section{PEMBAHASAN}

Karakteristik Responden

1. Karakteristik responden berdasarkan usia

Responden pada penelitian ini adalah wanita usia subur (WUS) di wilayah kerja UPTD Puskesmas Kampung Bangka Kecamatan Pontianak Tenggara. Berdasarkan tabel 4.1 yang dijelaskan pada bab IV diketahui bahwa usia WUS yang menjadi responden paling banyak dari kelompok intervensi dan kelompok kontrol adalah dewasa awal (26-35 th) dengan kisaran 25 responden $(47,2 \%)$ untuk kelompok intervensi dan 22 responden $(41,5 \%)$.

Penelitian ini sejalan dengan penelitian Mularsih, Cahyaningrum, dan Rubiyanti (2017) menjelaskan bahwa sebagian besar responden berusia 20-35 tahun sebanyak 23 responden $(54,8 \%)$. Pada penelitian Gustiana, Dewi, dan 
Nurchayati (2014) sebagian besar responden nya juga berusia 20-35 tahun bejumlah 68 tahun $(68,7 \%)$. Pada penelitian Rohmatin (2015) menjelaskan bahwa sebagian besar responden yang menggunakan kontrasepsi hormonal terdapat pada kelompok usia $<35$ tahun. Pada penelitian Awaliyah, Pradjatmo, dan Kusnanto (2017) didapatkan hasil bahwa penggunaan kontrasepsi hormonal, lama dan terakhir menggunakan kontrasepsi hormonal merupakan faktor yang berhubungan dengan kejadian kanker payudara.

Faktor usia dapat mempengaruhi bagaimana proses penerimaan dalam informasi yang diberikan. Pada usia dewasa biasanya terjadi proses penerimaan informasi yang lebih baik.Pada umumnya pengetahuan tentang kanker payudara lebih baik.Hal ini sejalan dengan hasil penelitian yang mana persepsi tentang pengetahuan sudah cukup baik.

2. Karakteristik responden berdasarkan tingkat pendidikan

Tingkat pendidikan terakhir WUS di wilayah kerja UPTD Puskesmas Kampung Bangka Kecamatan Pontianak Tenggara yang paling banyak untuk kelompok intervensi dan kelompok kontrol adalah tamatan SMA/SMK/Sederajat dengan kisaran 27 responden $(50,9 \%)$ untuk kelompok intervensi dan 26 responden $(49,1 \%)$ untuk kelompok kontrol. Hal ini sejalan dengan penelitian Dewi dan Hendrati (2015) yang menyebutkan tingkat pendidikan yang paling banyak pada respondennya adalah SMA atau sederajat yang berkisar 16 reponden $(35,6 \%)$ untuk kelompok intervensi dan 22 responden (48,9 \%) untuk kelompok kontrol.

Pada penelitian Hanifah (2015) yang dilakukan di wilayah kerja Puskemas Nusukan Surakarta responden WUS yang didapat memiliki tingkat pendidikan paling banyak SMA berjumlah 67 responden $(45,6 \%)$. Dalam penelitian Wicaksono (2013) menjelaskan bahwa tingkat pendidikan dapat mempengaruhi tingkat pengetahuan seseorang. Semakin tinggi tingkat pendidikan seseorang maka akan semakin baik pula tingkat pengetahuan seseorang. Tingkat pendidikan mempengaruhi seseorang dalam memperoleh pengetahuan, pemahaman, dan nilai-nilai lainnya yang akan membantu untuk berpikir lebih rasional dalam menyerap informasi.

Tingkat pendidikan dapat mempengaruhi seseorang dalam meningkatkan kemampuan untuk mencegah penyakit, dan kemampuan memelihara kesehatannya (Notoatmodjo, 2012). 
Pendidikan SMA merupakan jenjang pendidikan formal menengah. Pada penelitian ini pendidikan WUS terbanyak adalah SMA. Anggapan bahwa wanita akan mengurus rumah tangga membuat WUS tidak memiliki keinginan untuk menempuh pendidikan ke jenjang yang lebih tinggi. Hanya sebagian WUS yang merupakan tamatan perguruan tinggi.

\section{Karakteristik responden berdasarkan pekerjaan}

Sebagian besar pekerjaan responden di wilayah kerja UPTD Puskesmas Kampung Bangka Kecamatan Pontianak Tenggara sebagian besar berstatus ibu rumah tangga (IRT) sebanyak 40 responden $(75,7 \%)$ pada kelompok intervensi dan 42 (79,2\%) pada kelompok kontrol. Hal ini sejalan dengan penelitian Wirawan (2016) yang menyebutkan bahwa pekerjaan yang paling banyak adalah IRT berjumlah 141 responden (48,0\%). Dalam penelitian Septyasrini (2016) juga menyebutkan sebanyak 19 responden (61,3\%) bekerja IRT. Penelitian Astutik (2016) menunjukkan bahwa untuk responden yang bersatus IRT memiliki tingkat pengetahuan sedang.Menurut Notoatmodjo (2012) pekerjaan merupakan salah satu faktor lingkungan yang dapat mempengaruhi kesehatan.

Hal ini sejalan dengan hasil penelitian dalam persepsi pengetahuan sudah masuk kategori sedang dibanding perspektif yang lain. Sebagian besar WUS di wilayah kerja Puskesmas Kampung Bangka Kecamatan Pontianak Tenggara berstatus sebagai IRT hal ini dapat menyebabkan kurangnya interaksi dengan oranglain sehingga pengetahuan responden mengenai deteksi dini kanker payudara minim karena kurang mendapat informasi mengenai deteksi dini kanker payudara. Pengetahuan dapat meningkatkan kesadaran seseorang dalam menjaga kesehatan dengan upaya pencegahan penyakit.memiliki Pendidikan SMA sebanyak 8 orang $(53,3 \%)$. Penelitian yang dilakukan oleh Ramadi menunjukkan bahwa sebagian besar responden berpendidikan SMA yaitu sebanyak 44 orang (58\%) maka pendidikan memiliki pengaruh pada penyakit

Pengaruh Pendidikan Kesehatan Pemeriksaan Payudara Sendiri (SADARI) Terhadap Perilaku Deteksi Dini Kanker Payudara

Berdasarkan hasil penelitian yang dilakukan di wilayah kerja UPTD Puskesmas Kampung Bangka Kecamatan Pontianak Tenggara terhadap 106 responden yang terbagi dalam dua kelompok, 53 responden untuk kelompok intervensi dan 53 responden. Pada kelompok intervensi terdapat perubahan yang bermakna pada pre test dan post test pengetahuan dan persepsi dengan $p$-value 0,000 atau $\mathrm{p}<0,05$ dan untuk pre test dan 
post test perilaku SADARI juga didapatkan hasil perubahan yang bermakna dengan $p$-value 0,000 atau $\mathrm{p}<$ 0,05. Sedangkan untuk kelompok kontrol tidak terjadi perubahan yang bermakna pada pre test dan post test dengan nilau $p$ value 0,891 atau $\mathrm{p}>0,05$ dan untuk nilai pre test dan post test perilaku SADARI didapat $p$-value 1,000 atau $\mathrm{p}>0,05$ yang berarti tidak terdapat perubahan yang bermakna pula. Hal ini dapat disebabkan karena bedanya perlakuan yang diberikan kepada kelompok.Untuk kelompok intervensi diadakan pendidikan kesehatan mengenai deteksi dini kanker payudara tentang SADARI sedangkan untuk kelompok kontrol tidak diberikan.

Penelitian ini sejalan dengan penelitian Viviyawati (2014) yang menjelaskan bahwa terdapat pengaruh pendidikan kesehatan tentang pemeriksaan SADARI terhadap pengetahuan dan sikap pada remaja putri di SMK N 1 Karanganyar.Penelitian ini sejalan dengan penelitian Novasari, Nugroho, dan Winarni (2016) yang mengatakan bahwa terdapat hubungan antara pengetahuan dengan perilaku SADARI pada santriwati Pondok Pesantren Al Ishlah Tembalang Semarang.Penelitian ini juga didukung oleh penelitian Aprilliani (2015) yang menjelaskan bahwa terdapat hubungan tinkat pengetahuan tentang kanker payudara dengan perilaku SADARI. Penelitian ini juga didukung oleh penelitian Setyowati (2015) yang mengatakan bahwa terdapat pengaruh penyuluhan SADARI terhadap minat melakukan SADARI sebelum dan sesudah penyuluhan dengan nilai $p$-value $0,000<0,05$.

Menurut Notoatmodjo (2012) pengetahuan merupakan hasil dari tahu yang berarti mengingat sesuatu yang telah dipelajari atau diterima sebelumnya.Pengetahuan dapat diterima melalui penginderaan terhadap suatu objek. Penginderan melibatkan panca indra yang dimiliki oleh manusia, yakni indra penglihatan, pendengaran, rasa dan raba. Sebagian besar pengetahuan diperoleh dari mata dan telinga.Pengetahuan berperan sangat penting dalam membentuk perilaku seseorang. Pendidikan kesehatan merupakan suatu konsep pendidikan yang diterapkan dalam bidang kesehatan atau suatu kegiatan yang dapat membantu individu, kelompok, masyarakat dalam meningkatkan kemampuan atau perilaku dalam upaya mencapai kesehatan secara optimal (Marni, 2016). Pendidikan kesehatan identik dengan penyuluhan kesehatan, dimana keduanya berorientasi pada perubahan perilaku yang diharapkan, yaitu perilaku sehat, sehingga mempunyai kemampuan dalam mengenal masalah 
kesehatan individu, keluarga dan kelompok dalam upaya peningkatan kesehatan (Effendy, 2012).

Perilaku merupakan suatu tindakan atau perbuatan dari individu, baik yang dilakukan secara disadari maupun tidak disadari.Perilaku merupakan suatu bentuk dari respon individu yang dapat dipengaruhi oleh suatu stimulus atau tindakan yang diamati.Perilaku kesehatan terbagi dalam dua elemen yaitu elemen kognitif dan elemen afektif.Berperilaku sehat memerlukan tiga hal yaitu pengetahuan yang tepat, motivasi, dan keterampilan untuk berperilaku.Prosesproses perubahan kesehatan yaitu penilaian social, penilaian epidemiologi, penilaian perilaku dan lingkungan, mengidentifikasi faktor, pernilaian administrasi dan kerbijakan, implementasi dan evaluasi (Priyoto, 2015).

Dalam teori health belief model (HBM) menjelaskan bahwa perilaku seseorang dapat dipengarui oleh persepsi dan kepercayaan seseorang.Persepsi merupakan suatu pendapat individu terhadap sesuatu, tanpa memandang hal itu benar atau salah. Apabila persepsi seseorang mengenai suatu masalah kesehatan berubah maka hal tersebut akan mempengaruhi pada perubahan perilaku seseorang. Dengan dilakukan pendidikan kesehatan mengenai SADARI maka pandangan individu tersebut berubah sehingga muncul tindakan untuk melakukan SADARI (Priyoto, 2014).

Tingkat pendidikan rendah berpengaruh pada pemahaman seseorang terhadap penyakit kanker.Untuk pengetahuan, derajat penyakit, derajat kerentanan diperlukan pemahaman yang lebih atau mendalam tentang mekanisme penyakit dan gejala penyakit yang pada umumnya kurang tersosialisasikan pada pendidikan.Selain itu karakteristik responden terbatas dalam mencerna ilmu penyakit. Sehingga hasil penelitian menunjukkan bahwa untuk hasil pada pengetahuan, derajat penyakit dan kerentanan penyakit paling rendah disbanding perspektif yang lain. Hal ini sesuai dengan karakteristik responden.

Kegiatan pendidikan kesehatan yang dilaksanakan pada kelompok intervensi bertujuan untuk meningkatkan pengetahuan dan persepsi WUS terhadap kanker payudara, serta memberi informasi tentang deteksi dini kanker payudara sebagai upaya pencegahan terhadap kanker payudara yakni SADARI.Dalam penelitian yang telah dilakukan oleh peneliti, peningkatan pada pengetahuan dan persepsi WUS diikuti dengan adanya juga perubahan terhadap perilaku SADARI. Dengan meningkatkan pengetahuan WUS dapat membuat WUS lebih waspada dalam menjaga kesehatan melihat dari dampak yang 
akanditimbulkan apabila terkena kanker payudara sehinga keinginan WUS untuk melakukan SADARI meningkat.Oleh karena itu tahap selanjutnya dikembangkan media edukasi kesehatan berdasarkan informasi kuesioner yang diisi responden.

Media edukasi yang dipilih adalah leaflet telah banyak digunakan sebagai media edukasi yang bersifat informasi. Media leaflet dipilih karena dapat mudah digunakan dan dibawa kemana saja. Pada penelitian ini penjelasan dalam leaflet mengenai persepsi kerentanan dan derajat penyakit dikembangkan lebih terperinci yang bertujuan untuk meningkatkan persepsi kerentanan dan derajat penyakit sehingga dapat meningkatkan perilaku SADARI.

\section{SIMPULAN DAN SARAN}

Simpulan

Berdasarkan hasil penelitian dan pembahasan pengaruh pendidikan kesehatan SADARI terhadap perubahan perilaku SADARI pada WUS diwilayah puskesmas kampungbangka kecamatan Pontianak tenggara, maka dapat disimpulkan yaitu:

1. Karakteristik responden pada penelitian ini untuk usia responden yang terbanyak adalah berusia 26 - 35 tahun (dewasa awal) dengan jumlah 25 responden $(47,2 \%)$ pada kelompok intervensi dan 22 responden $(41,5 \%)$ pada kelompok kontrol. Untuk pendidikan terakhir yang terbanyak adalah SMA/SMK/Sederajat dengan jumlah 27 responden $(50,9 \%)$ pada kelompok intervensi dan 26 responden $(49,1 \%)$ pada kelompok kontrol. Untuk pekerjaan yang terbanyak adalah IRT sebanyak 40 responden (75,7\%) pada kelompok intervensi dan 42 responden $(79,2 \%)$ pada kelompok kontrol.

2. Terjadi perubahan yang bermakna terhadap pengetahuan dan persepsi pada kelompok intervensi p-value 0,000 atau $\mathrm{p}<0,05$, sedangkan pada kelompok kontrol tidak terjadi perubahan yang bermakna dengan nilai p-value 0,891 atau $\mathrm{p}>0,05$.

3. Untuk perilaku SADARI pada kelompok intervensi menunjukkan terdapat perubahan yang bermakna dengan nilai $p$-value 0,000 atau $p<0,05$, sedangkan untuk kelompok kontrol didapatkan hasil tidak terjadi perubahan yang bermakna pada perilaku SADARI.

4. Terdapat pengaruh pendidikan kesehatan SADARI terhadap perilaku deteksi dini kanker payudara pada WUS di wilayah kerja UPTD Puskesmas Kampung Bangka Kecamatan Pontianak Tenggara dengan nilai $\mathrm{p}$-value 0,000 atau $\mathrm{p}<0,05$. 
Berdasarkan penelitian dan pembahasan mengenai pengaruh pendidikan kesehatan SADARI terhadap perilaku deteksi dini kanker payudara pada WUS di wilayah puskesmas kampung bangka kecamatan Pontianak tenggara, peneliti ingin menyampaikan beberapa saran sebagai berikut:

1. SADARI merupakan pemeriksaan yang tidak mahal, tidak nyeri, tidak berbahaya dan nyaman. WUS diharapkan dapat melaksanakan SADARI secara rutin maupun dalam jangka waktu yang panjang untuk mendeteksi awal terjadinya kanker payudara.

2. Penelitian ini dapat dipergunakan sebagai bahan dan masukan dalam penelitian selanjutnya terkait dengan pengaruh terapi pendidikan kesehatan SADARI terhadap perubahan perilaku deteksi dini kanker payudara dan lebih memperhatikan faktor apa saja yang membuat penelitian menjadi bias.

\section{REFERENSI}

Astutik, R. P. (2016). Gambaran Tingkat Pengetahuan Wanita Usia Subur (WUS) Tentang Pemeriksaan Payudara Sendiri Sendiri (SADARI) Di Dusun Nganti Sleman Tahun 2015. Naskah Publikasi, Sekolah Tinggi Ilmu kesehatan 'Aisyiyah Yogyakarta. Diakses pada 22 Juli 2018 melalui http://digilib.unisayogya.ac.id/

Aprilliani, L. (2015). Hubungan Tingkat Pengetahuan Tentang Kanker Payudara Dengan Perilaku SADARI Pada Mahasiswa D III Kebidanan Semester IV Di Stikes 'Aisyiyah Yogyakarta.Naskah Publikasi, Sekolah Tinggi Ilmu Kesehatan 'Aisyiyah Yogyakarta. Diakses pada 22 Juli 2018 melalui http://digilib.unisayogya.ac.id/

Awaliyah, N., Pradjatmo, H., \& Kusnanto, H. (2017).Penggunaan Kontrasepsi Hormonal Dan Kejadian Kanker Payudara Di Rumah Sakit Dr. Sardjito.BKM Journal Of Community Medicine and Public Health vol. 33(10). Diakses pada 23 Juli 2018 melalui https://media.neliti.com/

Dewi, G. A. T., \& Hendrati, L. Y. (2015). Analisis Risiko Kanker Payudara Berdasarkan Riwayat Pemakaian Kontrasepsi Hormonal Dan UsiaMenarche. Jurnal Berkala Epidemiologi, Vol. 3, No. 1. Diakses pada 22
Juli 2018 melalui https://ejournal.unair.ac.id/

Dharma, K. K. (2015).Metodologi Penelitian Kesehatan. Jakarta : Trans Info Media.

Effendy, N. (2012). Dasar-Dasar Keperawatan Kesehatan Masyarakat Edisi 2. Jakarta: EGC.

Gustiana, D., Dewi, Y. I., \& Nurchayati, S. (2014). Faktor-Faktor Yang Berhubungan Dengan Perilaku Pencegahan Kanker Serviks Pada Wanita Usia Subur. JOM PSIK vol. 1(2). Diakses pada 23 juli 2018 melalui https://media.neliti.com/

Hanifah, A. N. (2015). Faktor-Faktor Yang Berhubungan Dengan Perilaku Wanita Usia Subur Dalam Melakukan Deteksi Dini Kanker Payudara Metode Sadari Di Wilayah Kerja Puskesmas Nusukan Surakarta. Naskah Publikasi. Diakses 22 Juli 2018melalui http://eprints.ums.ac.id/38172/

Integra.(2017). 7 Cara Menurunkan Resiko Kanker Payudara, Volume XVII.Bi-Monthly Buletin. Diakses pada tanggal 23 Januari 2018 melalui https://www.integra.co.id

Jarvis, S. (2009). Ensiklopedia Kesehatan Wanita. Jakarta : Erlangga.

Kementrian Kesehatan Republik Indonesia.(2013). Kanker Payudara.Infodatin. Diakses pada 19 Mei 2018 melalui http://www.depkes.go.id

Kementerian Kesehatan Republik Indonesia.(2015). Stop Kanker.Infodatin. Diakses pada 12 Februari 2018 melalui http://www.depkes.go.id

Kementrian Kesehatan Republik Indonesia.(2016). Kanker Payudara.Infodatin.ISSN: 24427659. Diakses pada 12 Februari 2018 melalui http://www.depkes.go.id

Kim, Jiyoung dkk.(2014). Breast Cancer Screening Knowledge and Perceived Health Beliefs among Immigrant Women in Korea.Journal of Breast Cancer, 17(3), 279-286. Diakses pada 14 Maret 2018 melalui https://www.ncbi.nlm.nih.gov/

Mularsih, S., Cahyaningrum, F., \& Rubiyanti, E.S. (2018). Hubungan Tingkat Pengetahuan Dengan Praktik SADARI Pada Wanita Usia Subur Di Kelurahan Kemijen Semarang Timur Kota Semarang. Jurnal Siklus Vol. 6 ISSN: 2549-5054. Diakses pada 23 juli 2018 melalui http://ejournal.poltektegal.ac.id

Notoatmodjo, S. (2012).Promosi Kesehatan Dan Perilaku Kesehatan. Jakarta: Rineka.

Novasari, D. H., Nugroho, D., \& Winarni, S. (2016). Hubungan Pengetahuan, Sikap Dan Paparan Media Informasi Dengan Praktik Pemeriksaan Payudara Sendiri (SADARI) Pada Santriwati Pondok Pesantren Al Ishlah Tembalang Semarang Tahun 2016. Jurnal Kesehatan Masyarakat Vol 4 (4) ISSN: 2356- 
3346. Diakses pada 22 Juli 2018 melalui https://ejournal3.undip.ac.id/

Priyoto, P. (2014). Teori Sikap Dan Perilaku Dalam Kesehatan. Yogyakarta: Nuha Medika.

Priyoto, P. (2015). Perubahan Dalam Perilaku Kesehatan. Yogyakarta: Graha Ilmu.

Rasjidi, I. (2010). Epidemiologi Kanker Pada Wanita. Jakarta: Sagung Seto.

Wardhani, A. D., Saraswati, L. D., \& Adi, M. S. (2017). Gambaran Pengetahuan Remaja Putri Tentang Sadari Dan Praktik Pemeriksaan Payudara Sendiri. Jurnal Kesehatan Masyarakat (e-Journal), 5(1), 2356-3346. Diakses pada 22 November 2017 melalui https://ejournal3.undip.ac.id

WHO.(2017). Cancer. Diakses pada 22 November 2017 melalui http://www.who.int/mediacentre

Wicaksono, P. P. (2013). Hubungan Tingkat Pendidikan Dengan Pengetahuan Ibu Rumah
Tangga Tentang Pap Smear Di Desa Kauman Kecamatan Tangen Kabupaten Sragen. Naskah Publikasi Universitas Muhammadiyah Surakarta. Diakses pada 22 juli 2018 http://eprints.ums.ac.id/

Wirawan, S. (2016). Profil Keterlambatan Terapi Akibat Keterlambatan Dokter Dan Sistem Pada Pasien Kanker Yang Dirujuk Ke Departemen Radioterapi RSUPN Dr. Cipto Mangunkusumo Periode Mei - Agustus 2015. Tesis, Universitas Indonesia. Diakses pada 22 Juli 2018 http://lib.ui.ac.id/

Yuliana, Y. (2018). Risiko Dan Deteksi Dini Kanker Payudara. $C D K-261,45(2)$.

Viviyawati, T. (2014).Pengaruh Pendidikan Kesehatan Tentang Pemeriksaan "SADARI" Sebagai Deteksi Dini Kanker Payudara Terhadap Pengetahuan Dan Sikap Remaja Putri Di SMK N 1 Karangayar.Unpublished, STIKES Kusuma Husada. 